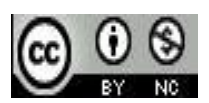

Jurnal Pendidikan Bahasa Indonesia is licensed under

A Creative Commons Attribution-Non Commercial 4.0 International Licens

\title{
Pengaruh Model Pembelajaran Problem Based Learning terhadap Hasil Belajar Menulis Teks Negosiasi Siswa Kelas X SMA Negeri 1 Singkawang Tahun Ajaran 2017/2018
}

\author{
Eti Sunarsih $^{1)}$, Suci Adelina ${ }^{2)}$, Lili Yanti ${ }^{3)}$ \\ 1. Program Studi Pendidikan Bahasa dan Sastra Indonesia STKIP Singkawang \\ Email: etisunarsih89@gmail.com \\ 2. Program Studi Pendidikan Bahasa dan Sastra Indonesia STKIP Singkawang \\ Email: sucyadelyna@gmail.com \\ 3. Program Studi Pendidikan Bahasa dan Sastra Indonesia STKIP Singkawang \\ Email: liliyantianal18@gmail.com
}

\begin{abstract}
Abstrak. Penelitian ini bertujuan untuk mengetahui pengaruh model pembelajaran problem based learning terhadap hasil belajar menulis teks negosiasi siswa kelas X SMA Negeri 1 Singkawang. Secara rinci tujuan penelitian adalah untuk mengetahui: (1) Perbedaan penggunaan model pembelajaran problem based learning dengan model pembelajaran langsung terhadap hasil belajar menulis teks negosiasi, (2) Mengetahui seberapa besar pengaruh penggunaan model pembelajaran problem based learning terhadap hasil belajar pada keterampilan menulis teks negosiasi, dan (3) Mengetahui aktivitas belajar siswa terhadap penggunaan model pembelajaran problem based learning pada keterampilan menulis teks negosiasi. Penelitian ini menggunakan metode ekperimen dengan bentuk Quasi experimental design dengan rancangan the nonequivalent posttesonly control group design. Teknik pengumpul data yang digunakan ialah teknik pengukuran, teknik observasi langsung, dan teknik dokumentasi. Alat pengumpul data yakni tes, lembar pengamatan aktivitas, dan dokumen. Berdasarkan hasil analisis data dapat disimpulkan bahwa: (1) Terdapat perbedaan hasil belajar siswa yang menggunakan model pembelajaran problem based learning dengan model pembelajaran langsung berdasarkan hasil perhitungan uji independent sample t-test diperoleh hasil $t_{\text {hitung }}$ 11,436 atau lebih besar dari $t_{\text {tabel }} 2,045$, (2) Besarnya pengaruh penggunaan model pembelajaran problem based learning terhadap hasil belajar menulis teks negosiasi dengan dibuktikan pada hasil uji effect size sebesar 0,98 atau lebih besar dari 0,8 termasuk ke dalam kategori tinggi, dan (3) Adanya ativitas belajar siswa yang menggunakan model pembelajaran problem based learning pada keterampilan menulis teks negosiasi dengan rata-rata persentase yaitu $85 \%$ yang termasuk ke dalam kriteria baik. Sehingga dapat disimpulkan bahwa penggunaan model pembelajaran problem based learning dapat meningkatkan hasil belajar siswa pada keterampilan menulis teks negosiasi siswa kelas X SMA Negeri 1 Singkawang.
\end{abstract}

Kata kunci : Model Pembelajaran; Problem Based Learning (PBL); menulis; teks negosiasi

\section{PENDAHULUAN}

Pendidikan merupakan suatu wadah dalam rangka mengembangkan kemampuan seseorang melalui kegiatan terencana dan sistematis. Pendidikan baik yang berjalan secara formal maupun informal diharapkan mampu mengasuh dan mendidik seseorang atau sekelompok orang agar dapat mengembangkan kemampuan, sikap, dan tingkah lakunya yang dianggap bernilai positif dan bermanfaat di masyarakat. Secara linguistis, sebagai kata benda pendidikan berarti proses perubahan sikap dan tingkah laku seseorang atau sekelompok orang dalam usaha mendewasakan manusia melalui pengajaran dan latihan (Poerwadarminta (dalam Tatang, 2012: 13)). Oleh karena itu, pendidikan sangat dibutuhkan dalam upaya mengembangkan kemampuan, sikap, dan tingkah laku melalui latihan atau pengajaran agar dapat mencapai tujuan yang dicita-citakan.

Aspek penting untuk mencapai kualitas pendidikan adalah dengan menguasai keempat keterampilan berbahasa dalam pembelajaran Bahasa Indonesia. Adapun empat 
keterampilan yang harus dikuasai siswa yakni pada keterampilan menyimak, berbicara, membaca, dan menulis (Tarigan, 2008: 1). Beberapa keterampilan berbahasa tersebut tentunya memiliki hubungan yang erat antara satu dengan lainnya. Jadi, dari keempat keterampilan berbahasa tersebut satu di antaranya yang dibicarakan adalah pada keterampilan menulis khususnya menulis teks negosiasi.

Berdasarkan hasil wawancara pada guru mata pelajaran bahasa Indonesia di SMA Negeri 1 Singkawang yaitu ibu Dewi Sartika, S. Pd menyatakan bahwa kemampuan siswa dalam menulis dikatakan masih rendah, sehingga banyak siswa yang belum mencapai KKM. Perlu diketahui nilai KKM yang harus dicapai oleh siswa pada mata pelajaran Bahasa Indonesia kelas X di SMA Negeri 1 Singkawang adalah 75. Padahal keterampilan menulis juga termasuk faktor penting yang harus dikuasai oleh siswa terutama dalam menuangkan ide atau gagasannya dalam bentuk tulisan. Selain itu minat dan motivasi belajar yang kurang terutama dalam kemampuan menulis siswa. Hal ini disebabkan oleh kurangnya kecakapan siswa dalam menulis, kurangnya pemahaman siswa dalam menulis, kurangnya minat siswa dalam menulis dan belum ditemukannya model pembelajaran yang tepat untuk melihat pengaruh keterampilan menulis siswa di kelas sehingga peneliti melakukan penelitian yang berhubungan dengan aspek menulis siswa pada kelas X SMA Negeri 1 Singkawang.

Menulis teks negosiasi akan lebih mudah apabila menggunakan model pembelajaran yang mendukung, Model pembelajaran yang digunakan adalah model problem based learning untuk mencari adanya pengaruh terhadap kemampuan siswa pada keterampilan menulisnya serta partisipasi siswa dalam belajar di kelas. Model pembelajaran problem based learning merupakan model pembelajaran yang menuntut pesert didik untuk berpikir kritis dalam memecahkan masalah di dalam situasi nyata mereka (Duck (dalam Shoimin, 2014: 130)). Model pembelajaran ini merupakan salah satu model pembelajaran inovatif yang dapat memberikan kondisi belajar aktif kepada siswa, yaitu melibatkan siswa untuk memecahkan suatu masalah yang mengarah pada suatu permasalahan yang berhubungan dengan situasi nyata siswa, sehingga dapat mendorong kemampuan siswa untuk membangun pengetahuannya melalui aktivitas belajar. Selain itu, aktivitas yang dilakukan bersifat ilmiah artinya berdasarkan pengamatan siswa dalam situasi nyata itu tadi.

Masalah umum dalam penelitian ini adalah "Apakah adanya pengaruh model pembelajaran problem based learning terhadap hasil belajar menulis teks negosiasi siswa kelas X SMA Negeri 1 Singkawang tahun ajaran 2017/2018?". Adapun sub-sub masalah yang dapat dirumuskan dalam penelitian ini sebagai berikut. (1) Apakah terdapat perbedaan penggunaan model pembelajaran problem based learning dengan model pembelajaran langsung terhadap hasil belajar menulis teks negosiasi siswa kelas X SMA Negeri 1 Singkawang? (2) Seberapa besar pengaruh penggunaan model pembelajaran problem based learning terhadap hasil belajar menulis teks negosiasi siswa kelas X SMA Negeri 1 Singkawang? (3) Bagaimanakah aktivitas belajar siswa terhadap penggunaan model pembelajaran problem based learning pada keterampilan menulis teks negosiasi siswa kelas X SMA Negeri 1 Singkawang?

Tujuan penelitian ini adalah untuk mengetahui: (1) Perbedaan penggunaan model pembelajaran problem based learning dengan model pembelajaran langsung terhadap hasil belajar menulis teks negosiasi siswa kelas X SMA Negeri 1 Singkawang, (2) Besar pengaruh penggunaan model pembelajaran problem based learning terhadap hasil belajar menulis teks negosiasi siswa kelas X SMA Negeri 1 Singkawang, (3) Aktivitas belajar siswa terhadap penggunaan model pembelajaran problem based learning pada keterampilan menulis teks negosiasi siswa kelas $\mathrm{X}$ SMA Negeri 1 Singkawang.

\section{METODE}

Metode yang digunakan dalam penelitian ini adalah metode eksperimen dalam jenis kuantitatif. Metode eksperimen adalah suatu cara yang dilakukan untuk mengungkapkan hubungan sebab akibat dua variabel atau lebih dengan mengendalikan pengaruh variabel yang lain (Nawawi (dalam Jakni, 2016: 2)). Metode penelitian eksperimen juga bisa diartikan sebagai metode yang digunakan untuk mencari pengaruh perlakuan tertentu terhadap masalah lain dalam kondisi yang dikendalikan (Sugiyono, 2015: 107). Desain yang digunakan dalam penelitian ini adalah Quasi Experimental Design.

Rancangan yang digunakan dalam penelitian ini adalah The Nonequivalent Posttes-Only Control Group Design. The nonequivalent posttes-only control group design dimana desain ini sampel yang diambil, baik kelompok eksperimen maupun kelompok kontrol tidak dipilih secara acak murni (random) (Lestari dan Yudhanegara, 2015: 139). Adapun yang menjadi populasi adalah seluruh siswa kelas X SMA Negeri 1 Singkawang. Populasi merupakan keseluruhan dari objek berupaka peristiwa maupun gejala yang menjadi sumber data penelitian (Sukandarrumidi, 2012: 47). Seluruh siswa kelas X SMA Negeri 1 Sigkawangyang berjumlah 170 orang. Peneliti menentukan sampel dengan menggunakan teknik purposive sampling. Teknik purposive sampling biasanya dilakukan karena didasarkan atas pertimbangan tertentu, misalnya alasan keterbatasan waktu, tenaga, dan dana (Arikunto, 2010: 183). Sehingga yang menjadi sampel dalam penelitian ini adalah kelas X IPS 1 sebagai kelas eksperimen dan kelas X IPS 2 sebagai kelas kontrol.

Teknik pengumpulan data yang digunakan ada 3 yaitu: teknik pengukuran, teknik observasi langsung, dan teknik dokumentasi. Teknik pengukuran ialah suatu cara untuk memperoleh hasil dalam bentuk angka (skor) untuk menunjukkan tingkat pencapaian seseorang pada bidang tertentu (Nurgiyantoro, 2010: 7). Kemudian teknik observasi langsung adalah cara untuk mengumpulkan data melalui pengamatan atau pencatatan terhadap gejala-gejala pada objek yang diamati (Nawawi, 2007: 94). Terakhir 
teknik dokumentasi merupakan teknik mencari dan mengumpkan data berupa catatan, transkrip, buku dan sebagainya (Arikunto, 2010: 274). Alat pengumpul data dalam penelitian ini berupa tes (esai), lembar pengamatan aktivitas, dan dokumen.

\section{HASIL DAN PEMBAHASAN}

\section{HASIL}

Hasil penelitian ini adalah untuk mengetahui pengaruh model pembelajaran problem based learning terhadap hasil belajar menulis teks negosiasi siswa kelas X SMA Negeri 1 Singkawang tahun ajaran 2017/2018. Adapun hasil yang diperoleh dari penelitian ini meliputi, hasil belajar siswa antara kelas eksperimen yang menggunakan model pembelajaran problem based learning dan kelas kontrol yang menggunakan model pembelajaran langsung pada keterampilan menulis teks negosiasi.

Hasil nilai rata-rata kedua kelas setelah melalui perhitungan bahwa pada kelas eksperimen adalah 79,96 sedangkan nilai rata-rata kelas kontrol adalah 72,96. Data tersebut diperoleh dari hasil jawaban siswa pada soal posttest. Berikut diagram yang menunjukkan tingkatan nilai rata-rata posttes kedua kelas dapat dilihat pada Gambar 1 di bawah ini.

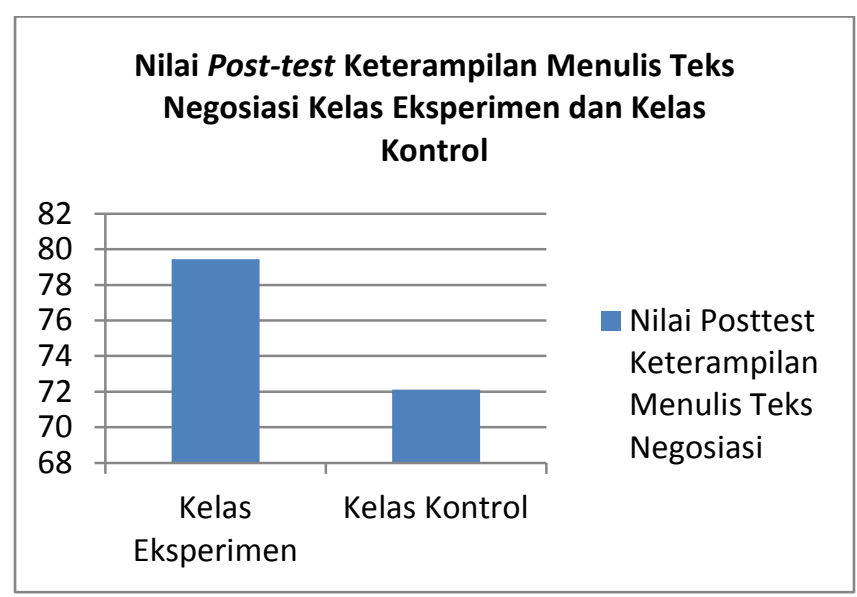

Gambar 1 Nilai Posstest Keterampilan Menulis Teks Negosiasi Kelas Eksperimen dan Kelas Kontrol

Setelah dilakukan uji normalitas data menggunakan uji liliefors diperoleh hasil $\mathrm{L}_{\mathrm{hitung}}$ kelas eksperimen 0,1130 dan $\mathrm{L}_{\text {hitung }}$ kelas kontrol 0,0824 yang berarti $\mathrm{L}_{\text {hitung }}$ keduanya lebih kecil dari $\mathrm{L}_{\text {tabel }} 0,1611$ sehingga data dikatakan berdistribusi normal. Sedangkan uji homogenitas data menggunakan uji fisher diperoleh hasil $\mathrm{F}_{\text {hitung }} 1,44$ atau lebih kecil dari pada $\mathrm{F}_{\text {tabel }} 1,88$ sehingga data dikatakan bersifat homogen. Kemudian tahap selanjutnya mencari perbedaan dua rerata kelas eksperimen dan kelas kontrol dengan uji independent sample t-test.
Tabel 1. Rekapitulasi Perhitungan Dua Rata-rata Kelas Eksperimen dan Kelas Kontrol

\begin{tabular}{|c|c|c|c|c|c|c|}
\hline Keterangan & $\sum X_{1}$ & $\sum X_{2}$ & $\overline{X_{1}}$ & $\overline{X_{2}}$ & $S_{1}^{2}$ & $S_{2}^{2}$ \\
\hline Skor & 2239 & 2043 & 79,96 & 72,96 & 10,32 & 7,17 \\
\hline $\mathrm{t}_{\text {hitung }}$ & \multicolumn{7}{|c|}{11,436} \\
\hline $\mathrm{t}_{\text {tabel }}$ & \multicolumn{7}{|c|}{2,045} \\
\hline
\end{tabular}

Keterangan:

$\sum X_{1} \quad=$ jumlah rata-rata keseluruhan kelas eksperimen

$\sum X_{2}=$ jumlah rata-rata keseluruhan kelas kontrol

$\overline{X_{1}} \quad=$ rata-rata kelas eksperimen

$\overline{X_{2}} \quad=$ rata-rata kelas kontrol

$S_{1}^{2} \quad=$ varians kelas eksperimen

$S_{2}^{2} \quad=$ varians kelas kontrol

Berdasarkan tabel 1 diketahui bahwa $t_{\text {hitung }} 11,436$ atau lebih besar dari $t_{\text {tabel }} 2,045$. Karena $t_{\text {hitung }}>t_{\text {tabel }}$ maka Ha diterima. Artinya terdapat perbedaan hasil belajar siswa yang menggunakan model pembelajaran problem based learning dengan model pembelajaran langsung.

Selanjutnya untuk mengetahui seberapa besar pengaruh model pembelajaran problem based learning terhadap hasil belajar menulis teks negosiasi siswa kelas $\mathrm{X}$ SMA Negeri 1 Singkawang dilakukan pengujian dengan menggunakan rumus effect size.

Tabel 2. Rekapitulasi Hasil Perhitungan Effect Size Siswa Kelas Eksperimen dan Kelas Kontrol

\begin{tabular}{|c|c|c|}
\hline Keterangan & $\begin{array}{c}\text { Kelas } \\
\text { Eksperimen }\end{array}$ & Kelas Kontrol \\
\hline SD & 10,32 & 7,17 \\
\hline Effect Size (Es) & \multicolumn{2}{|c|}{0,98} \\
\hline Kriteria & \multicolumn{2}{|c|}{ Tinggi } \\
\hline
\end{tabular}

Berdasarkan Tabel 2 perhitungan effect size diperoleh hasil sebesar 1,33. Karena Es= 1,33>0.8 jadi dapat dikatakan termasuk ke dalam kriteria tinggi. Hal ini dapat disimpulkan bahwa terdapat pengaruh model pembelajaran problem based learning terhadap hasil belajar menulis teks negosiasi siswa kelas X SMA Negeri 1 Singkawang tahun ajaran 2017/2018.

Terakhir menghitung hasil pengamatan aktivitas siswa baik kelas eksperimen maupun kelas kontrol. Peneliti menghitung lembar pengamatan aktivitas dengan menggunakan persentase. Adapun rekapitulasi hasil pengamatan aktivitas siswa selama dua kali pertemua sebagai berikut.

Tabel 3. Rekapitulasi Hasil Pengamatan Aktivitas Belajar Siswa Secara Keseluruhan

\begin{tabular}{|c|c|c|c|}
\hline & Pengamat & $\begin{array}{c}\text { Kelas } \\
\text { Eksperimen }\end{array}$ & $\begin{array}{c}\text { Kelas } \\
\text { Kontrol }\end{array}$ \\
\hline Pertemuan & 1 & $84 \%$ & $54 \%$ \\
\hline
\end{tabular}




\begin{tabular}{|c|c|c|c|}
\hline \multirow[t]{2}{*}{1} & 2 & $85 \%$ & $54 \%$ \\
\hline & 3 & $86 \%$ & $53 \%$ \\
\hline \multirow{3}{*}{$\begin{array}{l}\text { Pertemuan } \\
2\end{array}$} & 1 & $83 \%$ & $55 \%$ \\
\hline & 2 & $85 \%$ & $55 \%$ \\
\hline & 3 & $85 \%$ & $53 \%$ \\
\hline \multicolumn{2}{|c|}{ Rata-rata } & $85 \%$ & $54 \%$ \\
\hline \multicolumn{2}{|c|}{ Kriteria } & Baik & Kurang \\
\hline
\end{tabular}

Berdasarkan Tabel 4 dapat diketahui rata-rata keseluruhan persentase pada kelas eksperimen sebesar $85 \%$ dengan kriteria baik sedangkan pada kelas kontrol diperoleh sebesar 54\% dengan kriteria kurang. Hasil persentase kelas eksperimen menunjukkan hasil yang lebih tinggi dibanding dengan kelas kontrol. Sehingga dapat disimpulkan bahwa adanya pengaruh model pembelajaran problem based learning terhadap aktivitas belajar siswa pada keterampilan menulis teks negosiasi.

Faktor yang mempengaruhi aktivitas belajar siswa tinggi adalah model pembelajaran problem based learning menuntut siswa dapat aktif dan mandiri pada aktivitas siswa di dalam kegiatan pembelajaran dengan cara menemukan dan memecahkan masalah yang berhubungan dengan masalah disituasi nyata mereka. Sehingga siswa tidak hanya terampil dalam memecahkan masalah tetapi juga memperoleh ilmu pengetahuan yang bermanfaat dari pengalaman belajar. Adapun diagram batang rekapitulasi hasil perhitungan aktivitas belajar siswa pada seluruh pertemuan sebagai berikut.

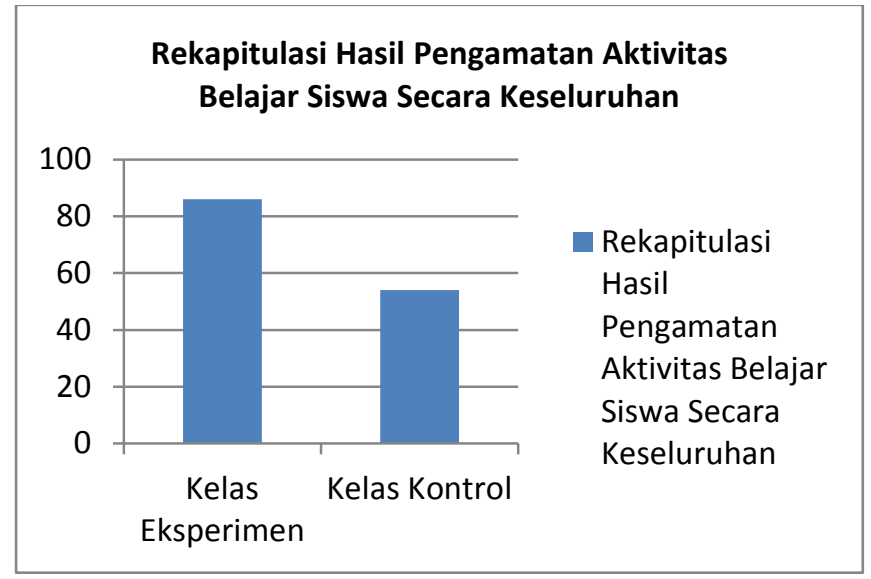

Gambar 4.5 Rekapitulasi Hasil Pengamatan Aktivitas Belajar Siswa

\section{PEMBAHASAN}

Berdasarkan hasil analisis data yang telah dilakukan, untuk mengetahui perbedaan hasil dari kedua kelompok dilakukan perhitungan dengan menggunakan uji independent sample t-test. Sebelumnya peneliti menghitung nilai rata-rata posstest kelas eksperimen maupun kelas kontrol sekaligus menghitung standar deviasi keduanya. Nilai rata-rata kelas eksperimen adalah 79,96 dengan standar deviasi 10,32 sedangkan kelas kontrol adalah 72,96 dengan standar deviasi 7,17. Selanjutnya perhitungan dengan menggunakan uji independent sample t-test memperoleh hasil $t_{\text {hitung }} 11,436$ atau lebih besar dari $t_{\text {tabel }}$ 2,045. Karena $t_{\text {hitung }}>t_{\text {tabel }}$ maka Ha diterima dan Ho ditolak. Jadi, dapat disimpulkan bahwa terdapat berbedaan penggunaan model pembelajaran problem based learning dengan model pembelajaran langsung terhadap hasil belajar menulis teks negosiasi siswa kelas X SMA Negeri 1 Singkawang.

Setelah mengetahui perbedaan hasil belajar kedua kelompok, maka tahap selanjutnya menghitung besarnya pengaruh penggunaan model pembelajaran problem based learning. Hasil perhitungan menunjukkan terdapat pengaruh penggunaan model pembelajaran problem based learning terhadap hasil belajar menulis teks negosiasi siswa kelas $\mathrm{X}$ SMA Negeri 1 Singkawang. Hal ini dapat dilihat dari hasil effect size sebesar 0,98>0,8 termasuk ke dalam kriteria tinggi.

Hasil pengamatan aktivitas belajar siswa baik kelas eksperimen maupun kelas kontrol pada pertemuan pertama dan kedua menunjukkan hasil yang cukup signifikan. Berdasarkan hasil perhitungan dengan menggunakan rumus persentase diperoleh hasil untuk kelas eksperimen sebesar 85\% dengan kriteria baik sedangkan pada kelas kontrol sebesar 54\% dengan kriteria kurang. Sehingga dapat disimpulkan bahwa penggunaan model pembelajaran problem based learning juga mempengaruhi aktivitas belajar siswa pada keterampilan menulis teks negosiasi.

\section{SIMPULAN DAN SARAN}

\section{SIMPULAN}

Berdasarkan hasil penelitian dan pembahasan yang telah disajikan, secara umum dapat disimpulkan bahwa "Terdapat pengaruh model pembelajaran problem based learning terhadap hasil belajar menulis teks negosiasi siswa kelas X SMA Negeri 1 Singkawang tahun ajaran 2017/2018". Secara khusus dapat disimpulkan dalam beberapa hal sebagai berikut. (1) Adanya perbedaan penggunaan model pembelajaran problem based learning dengan model pembelajaran langsung terhadap hasil belajar menulis teks negosiasi siswa kelas X SMA Negeri 1 Singkawang tahun ajaran 2017/2018. Berdasarkan hasil perhitungan, $t_{\text {hitung }}$ yakni sebesar 11,436 yang artinya lebih besar dari $t_{\text {tabel }}$ (2,045), (2) Adanya pengaruh model pembelajaran problem based learning terhadap hasil belajar menulis teks negosiasi siswa kelas X SMA Negeri 1 Singkawang tahun ajaran 2017/2018. Berdasarkan hasil perhitungan, maka effect size (Es) yakni sebesar 0,98 atau lebih besar dari 0,8. Artinya masuk ke dalam kriteria tinggi, dan (3) Adanya aktivitas belajar siswa terhadap penggunaan model pembelajaran problem based learning pada keterampilan menulis teks negosiasi dengan rata-rata persentase keseluruhan sebesar $85 \%$ dengan kriteria baik. 


\section{SARAN}

Berdasarkan keberhasilan model pembelajaran problem based learning yang memberikan pengaruh terhadap hasil belajar menulis teks negosiasi pada siswa kelas X SMA Negeri 1 Singkawang, maka saran yang dapat peneliti berikan adalah sebagai berikut. (1) Berdasarkan hasil penelitian, dapat diketahui penggunaan model pembelajaran problem based learning memiliki pengaruh yang besar terhadap materi menulis teks negosiasi dibanding dengan model pembelajaran langsung. Oleh karena itu, diharapkan hasil penelitian ini dapat memberi manfaat bagi sekolah agar tercapainya tujuan pembelajaran terutama pada pembelajaran Bahasa Indonesia, (2) Selama proses pembelajaran diharapkan guru dapat menerapkannya dengan sebaik mungkin dan atau mengembangkan model pembelajaran problem based learning dengan metode yang lain sebagai inovasi baru agar menciptakan kegiatan pembelajaran yang efektif dan menarik, (3) Penerapan model pembelajaran problem based learning diharapkan dapat menjadi alternatif dalam meningkatkan motivasi belajar siswa terutama pada keterampilan menulis teks negosiasi, dan (4) Penelitian ini diharapkan dapat menjadi bahan pertimbangan untuk melakukan penelitian lanjutan dengan hasil yang diharapkan sebagai referensi lebih lanjut pada penelitian ke depan.

\section{DAFTAR PUSTAKA}

Arikunto, Suharsimi. (2010). Prosedur Penelitian. Jakarta: Rineka Cipta.

Jakni. (2016). Metodologi Penelitian Eksperimen Bidang Pendidikan. Bandung: ALFABETA.

Lestari, Karunia Eka dan Mokhammad Ridwan Yudhanegara. (2017). Penelitian Pendidikan Matematika. Bandung: PT Refika Aditama.

Nawawi, Hadari. (2007). Metode Penelitian Bidang Sosial. Yogyakarta: Gdjah Mada University Press.

Nurgiyantoro, Burhan. (2010). Penilaian Pembelajaran Bahasa Berbasis Kompetensi. Yogyakarta: BPFEYOGYAKARTA.

Shoimin, Aris. (2014). 68 Model Pembelajaran Inovatif dalam Kurikulum 2013. Yogyakarta: AR-RUZZ MEDIA.

Sugiyono. (2015). Metode Penelitian Pendidikan (Pendekatan Kuantitatif, Kualitatif, dan R\&D). Bandung: Alfabeta.

Sukandarrumidi. (2012). Metode Penelitian. Yogyakarta: Gadjah Mada University Press.

Tarigan, Henry Guntur. (2008). Menulis. Bandung: Angkasa.

Tatang. (2012). Ilmu Pendidikan. Bandung: Pustaka Setia. 